\title{
PENERAPAN PERANGKAT PEMBELAJARAN BERBASIS PRAKTIKUM INVERTEBRATA UNTUK MENINGKATKAN KEMAMPUAN BERPIKIR KRITIS DAN SIKAP ILMIAH SISWA SMA
}

\author{
Muttaqien Mafaza $^{1}$, Sri Mulyani $\mathbf{E}^{\mathbf{1}}$, Saiful Ridlo ${ }^{1}$ \\ ${ }^{1}$ Prodi Pendidikan Ilmu Pengetahuan Alam \\ Program Pascasarjana Universitas Negeri SemarangIndonesia \\ 1'muttaqien.mafaza@gmail.com
}

Citasi: Mafaza, M., Mulyani, S., \& Ridlo, S. 2018.Penerapan Perangkat Pembelajaran Berbasis Praktikum Invertebrata Untuk Meningkatkan Kemampuan Berpikir Kritis Dan Sikap Ilmiah Siswa SMA. Mangifera Edu Vol 2 Nomor 2. Hal 103-114

\begin{abstract}
ABSTRAK
Belajar dipandang sebagai proses merumuskan pengetahuan pengalaman konkret, aktivitas kolaboratif dan refleksi dan interpretasi. Oleh karena itu, pembelajaran berbasis praktik dapat digunakan sebagai alternatif pembelajaran yang dapat mendorong siswa untuk belajar aktif untuk merekonstruksi pemahaman konseptual penelitian ini menerapkan laboratorium pembelajaran berbasis masalah sehingga sulit untuk belajar akan konkret dan mudah dimengerti. Upaya ini dilakukan agar siswa dapat meningkatkan keterampilan berpikir kritis dan sikap ilmiah mahasiswa. Populasi penelitian ini adalah siswa SMA Daar El Qolam Boarding School Jayanti Tangerang. etode yang digunakan dalam penelitian ini adalah kuasi-eksperimen dengan "pretest-posttest control group design". Nilai pengembangan awal sikap ilmiah untuk rata-rata kelas eksperimen adalah 76,68 sedangkan kelas kontrol adalah 75,18. Setelah proses pembelajaran menunjukan siswa telah memiliki sikap ilmiah dalam pembelajaran biologi hal ini dibuktikan dengan meningkatnya hasil nilai rata-rata sikap ilmiah siswa yaitu 84,5 untuk kelas eksperimen dan 77,88 untuk kelas kontrol. Kemudian di uji beda 2 rata-rata dengan hasil sikap ilmiah awal siswa kelas eksperimen dan kelas kontrol terhadap pembelajaran berbeda signifikan. Hal ini juga didukung dari hasil angket dan wawancara guru dengan siswa.
\end{abstract}

\section{Kata kunci: Berpikir Kritis, Sikap Ilmiah, Pembelajaran Berbasis Praktikum}

\section{PENDAHULUAN}

Pendidikan merupakan suatu usaha yang dilakukan secara sadar dan sengaja untuk mengubah tingkah laku manusia baik secara individu maupun kelompok dan mendewasakan manusia melalui upaya pengajaran dan latihan (Sugiharto, 2007). Pembelajaran secara umum adalah suatu kegiatan yang dilakukan oleh guru sedemikian rupa sehingga tingkah laku siswa berubah ke arah yang lebih baik. Selain menguasai konsep, siswa juga harus mampu untuk berpikir tingkat tinggi, salah satunya berpikir kritis (Liliasari, 2000).

Salah satu masalah yangdihadapi dunia pendidikan Indonesia sekarang ini adalah masih lemahnya prosespembelajaran. Dalam proses pembelajaran, siswa kurang didorong untukmengembangkan kemampuan berpikirnya. Pembelajaran diarahkan untuk menghafal 
dan menimbun informasi, sehingga siswa pintar secara teoritis tetapimiskin aplikasi. Misalnya pada mata pelajaran sains tidak dapat mengembangkankemampuan peserta didik untuk berpikir kritis dan sistematis, karena strategipembelajaran berpikir tidak digunakan secara baik dalam setiap proses pembelajaran (Sanjaya, 2006). Perlu adanya peningkatan siswa dalam mengembangkan berpikir kritis pada siswa.

Tytler (2002), menyatakanpentingnya memperkuat pengetahuan awal siswa. Untuk mencapai haltersebut maka salah satu metode pembelajaran yang dapat digunakan adalah metode praktikum. Metode praktikum memungkinkan siswa belajar suatu konsep secara langsung melalui observasi atau pengamatan, mencoba dan bereksperimen sehingga meningkatkan pemahaman konsep. Pada pembelajaranberbasis praktikum, belajar lebih diarahkan pada experimental learning berdasarkan pengalaman konkrit, dan diskusi dengan teman yang selanjutnya akan diperoleh ide dan konsep baru.

Belajar dipandang sebagai proses penyusunan pengetahuan dari pengalaman konkrit, aktivitas kolaboratif dan refleksi serta interpretasi. Oleh karena itu, pembelajaran berbasis praktikum dapat digunakan sebagai alternatif pembelajaran yang dapat mendorong siswa belajar aktif untuk merekonstruksi kembali pemahaman konseptualnya (Gasong, 2006). Menurut Koray \& Koskal (2009), pelaksanaan aplikasi laboratorium untuk meningkatkan kemampuan berpikir kritis, kreatif dan logis bagi calon guru dapat berhasil.

Mimbs,(2005) menyatakan bahwa guru perlu model pemikiran kritis dan mempraktekkannya, menggunakan dalam pendekatan pembelajarannya. Siswa juga perlu untuk menggunakan keterampilan berpikir kritis mereka sehingga dapat memanfaatkan keterampilan tersebut untuk kegiatan yang lain. Pendidikan sains perlu memupuk sikap ilmiah melalui pembelajaran berpraktikum. Oleh karena itu penelitian ini juga menganalisis sikap ilmiah siswa. Salah satu assesmen yang digunakan dalam penelitian ini adalah assesmen kinerja. Performance assessment atau penilaian kinerja siswa dapat digunakan untuk mengumpulkan bukti-bukti kemajuan belajar siswa secara aktual, serta untuk memperoleh gambaran tentang profil siswa secara lengkap. Penilaian kinerja dirasakan lebih adil dan fair bagi siswa, serta dapat meningkatkan motivasi siswa untuk terlibat aktif dalam proses pembelajaran.

Hasil pembelajaran Invertebrata kelas 1 SMA di Pondok Pesantren Daar el-Qolam pada tahun 2011-2012 menunjukkan hasil yang masih kurang mencapai KKM (7.0), yaitu 6.5. Dari beberapa indikator permasalahan yang ada, yaitu sebagai berikut: 1) Pembelajaran yang selama ini dilakukan lebih banyak menggunakan metode ceramah dan cenderung kurang melibatkan siswa, sehingga monoton dan searah. 2) Karena kondisi pembelajaran 
yang monoton dan searah sehingga perhatian siswa belum terfokuskan. 3) Proses pembelajaran belum banyak ditunjang metode lain seperti eksperimen/pengamatan secara maksimal sebagai penunjang teori yang sudah ada. 4) Laboratorium yang dimiliki kurang di manfaatkan dalam pembelajaran meskipun alat-alat yang tersedia cukup memadai.

Atas dasar uraian pada latar belakang di atas diasumsikan bahwa beberapa masalah tersebut merupakan penyebab kurangnya hasil belajar siswa sehingga perlu adanya upaya untuk meningkatkan hasil belajar siswa, kemampuan berpikir kritis siswa dan sikap ilmiah siswa. Solusi permasalahan yang diajukan adalah dapatkah pembelajaran berbasis praktikum dapat meningkatkan kemampuan berpikir kritis siswa dan sikap ilmiah siswa SMA Daar elQolam Jayanti Tangerang.

\section{METODE PENELITIAN}

Penelitian dilakukan pada dua kelas yang memiliki kemampuan setara. Subjek dalam penelitian ini adalah siswa kelas X di SMA Daar el-Qolam di Kabupaten Tangerang Propinsi Banten semester genap tahun ajaran 2012/2013 sebanyak 10 kelas.

Metode yang digunakan dalam penelitian ini adalah quasi experiment.(Wiersma, 1994), dengan “control group pretes-postes design" (Fraenkel \& Wallen, 2006). Control group adalah pengambilankelompok secara acak kelas, terdapat kelompok pembanding, masing-masing kelompok diberi tes awal dan tes akhir dengan perlakuan yang berbeda. Bentuk desain penelitian yang digunakan yaitu "control group pretes-postes design".

\section{Tabel 1 Desain Penelitian}

\begin{tabular}{ccc}
\hline Pre tes & Perlakuan & Post tes \\
\hline kelas kontrol & pembelajaran ceramah & kelas kontrol \\
kelas eksperimen & pembelajaran praktikum & kelas eksperimen \\
\hline
\end{tabular}

\section{HASIL DAN PEMBAHASAN}

Kemampuan berpikir kritis siswa pada Konsep invertebrate 
Hasil penenlitian mengenai berpikir kritis siswa pada konsep invertebrata diperoleh dari hasil pre tes dan pos tes. data tentang nilai pre tes dan pos tes siswa kelas eksperimen dengan kontrol ditampilkan dalam Tabel 2 berikut.

Tabel 2 Nilai pre tes dan pos tes kelas eksperimen dan kelas control

\begin{tabular}{|c|c|c|c|c|c|c|c|}
\hline \multirow[b]{2}{*}{ Nilai } & \multirow[b]{2}{*}{ Kelas } & \multirow[b]{2}{*}{$\mathrm{N}$} & \multicolumn{5}{|c|}{ Tes Kemampuan Berpikir Kritis } \\
\hline & & & $\begin{array}{c}\text { Nilai } \\
\text { maksimal }\end{array}$ & $\begin{array}{c}\text { nilai } \\
\text { minimal } \\
\text { yang } \\
\text { diperoleh }\end{array}$ & $\begin{array}{c}\text { nilai } \\
\text { maksimal } \\
\text { yang } \\
\text { diperoleh }\end{array}$ & $\bar{X}$ & S \\
\hline Pre & eksperimen & 32 & & 57 & 78 & 67.84 & 5.14 \\
\hline tes & kontrol & 32 & 100 & 47 & 75 & 65.28 & 6.49 \\
\hline pos & eksperimen & 32 & & 66 & 93 & 81.37 & 5.92 \\
\hline tes & kontrol & 32 & 100 & 66 & 79 & 73.5 & 3.89 \\
\hline range & & & & & & & \\
\hline & Imlah subyek & (SIS) & & & & & \\
\hline & ata-rata nilai & & & & & & \\
\hline & tandart devias & & & & & & \\
\hline
\end{tabular}

Berdasarkan Tabel 2 diketahui bahwa rata-rata nilai awal siswa kelas eksperimen dan kelas kontrol pada konsep invertebrata yang berbeda. Setelah pembelajaran nilai yang diperoleh siswa kelas eksperimen dan kelas kontrol mengalami perubaha. Nilai kelas eksperimen perkembangan nilainya lebih tinggi dibandingkan kelas kontrol.

Selanjutnya, untuk mengetahui signifikansi perbedaan rata-rata pre tes dan pos tes kemampuan berpikir kritis kelas eksperimen dengan kelas kontrol, data nilai terlebih dahulu dilakukan uji normalitas dan homogenitas data pre tes. Hasil pengujiannya adalah normal dan homogen. Selanjutnya data diuji dengan menggunakan uji perbedaan dua rata-rata.

a. Uji Perbedaan Rata-rata Nilai Pre tes Kemampuan berpikir kritis Siswa Kelas Eksperimen dan Kelas Kontrol.

Tabel 3 Hasil Uji Beda Dua Rata-rata Nilai Pre tes Kemampuan Berpikir Kritis Siswa Kelas Eksperimen dan Kelas Kontrol

\begin{tabular}{|c|c|c|c|c|c|c|c|c|}
\hline Data & Kelas & $\mathrm{N}$ & $\bar{X}$ & $\mathrm{~S}$ & $\mathrm{t}_{\mathrm{tab}}$ & $t_{\text {hit }}$ & $\begin{array}{l}\text { Penerimaan } \\
\mathrm{H}_{0}(\alpha=0.05)\end{array}$ & Kesimpulan \\
\hline Pre tes & $\begin{array}{c}\text { Eksperim } \\
\text { en } \\
\text { Kontrol }\end{array}$ & 32 & $\begin{array}{r}67.84 \\
65.28\end{array}$ & $\begin{array}{l}5.14 \\
6.49\end{array}$ & 2.039 & 1.75 & Terima $\mathrm{H}_{0}$ & $\begin{array}{c}\text { Tidak } \\
\text { Berbeda } \\
\text { Signifikan }\end{array}$ \\
\hline
\end{tabular}

Keterangan :

$\begin{array}{llll}\mathrm{N} & \text { : Jumlah siswa } & \mathrm{t}_{\text {hit }} & \text { : nilai hasil perhitungan uji } \mathrm{t} \\ \bar{X} & \text { : rata-rata nilai } & \mathrm{t}_{\mathrm{tab}} & \text { : nilai } \mathrm{t} \text { tabel } \\ \mathrm{S} & \text { : Standar deviasi } & & \end{array}$


b. Uji Beda dua Rata-rata Nilai Pos tes Kemampuan Berpikir Kritis Kelas Eksperimen dan Kelas Kontrol.

Tabel 4 Hasil Uji Beda Dua Rata-rata Nilai Pos Tes Kemampuan Berpikir Kritis Siswa Kelas Eksperimen dan Kelas Kontrol

\begin{tabular}{|c|c|c|c|c|c|c|c|c|}
\hline Data & Kelas & $\mathrm{N}$ & $\bar{X}$ & $\mathrm{~S}$ & $t_{\text {tab }}$ & $t_{\text {hit }}$ & $\begin{array}{l}\text { Penerimaan } \\
\mathrm{H}_{0}(\alpha=0.05)\end{array}$ & Kesimpulan \\
\hline \multirow{2}{*}{$\begin{array}{l}\text { Pos } \\
\text { tes }\end{array}$} & Eksperimen & 32 & 88 & 4.83 & \multirow[b]{2}{*}{1.69} & \multirow[b]{2}{*}{16.88} & \multirow[b]{2}{*}{ Tolak $\mathrm{H}_{0}$} & \\
\hline & Kontrol & 32 & 73.5 & 3.89 & & & & $\begin{array}{c}\text { Berbeda } \\
\text { Signifikan }\end{array}$ \\
\hline
\end{tabular}

Keterangan :

$\mathrm{N} \quad$ : Jumlah siswa $\quad \mathrm{t}_{\text {hit }} \quad$ : nilai hasil perhitungan uji $\mathrm{t}$

$\bar{X} \quad$ : rata-rata nilai $\quad t_{\text {tab }} \quad$ : nilai $\mathrm{t}$ tabel

S : Standar deviasi

Berdasarkan data dalam Tabel 4 diperoleh thitung nilai pos tes kemampuan berpikir kritis kelas eksperimen dan kelas kontrol berada di luar daerah t kritis untuk $\alpha=0.05$ satu pihak, $\mathrm{H} 0$ diterima jika $t_{\alpha, \mathrm{db}} \geq \mathrm{t}_{\text {hitung }}$. Karena $\mathrm{t}_{\text {tabel }} \pm 1.69$ dan $\mathrm{t}_{\text {hitung }}$ nilai pos tes $=16.88$ sehingga dapat disimpulkan bahwa $\mathrm{H} 0$ pos tes ditolak. Hal ini dapat diartikan bahwa kemampuan berpikir kritis siswa kelas eksperimen dan kelas kontrol sesudah pembelajaran terhadap pembelajaran biologi berbeda signifikan.

c. Perhitungan Gain Ternormalisasi (N-gain) Kemampuan Berpikir Kritis siswa Kelas eksperimen dan Kelas Kontrol.

Katagori perkembangan kemampuan berpikir kritis siswa kelas eksperimen dan kelas kontrol dapat diketahui dengan melalukan penghitungan gain ternormalisasi ( $\mathrm{N}$-gain). Persentase perkembangan kemampuan berpikir kritis siswa pada konsep invertebrata berdasarkan $\mathrm{N}$-gain kelas kesperimen dan kelas kontrol disajikan dalam Tabel 5berikut ini.

Tabel 5 Gain Ternormalisasi Kemampuan berpikir kritis Siswa Kelas Eksperimen
\begin{tabular}{ccccc} 
& \multicolumn{3}{c}{ dan Kelas Kontrol } \\
\hline Kelas & Jumlah & Jumlah & Rata-rata & Katagori \\
& Siswa (N) & & & \\
\hline Eksperimen & 32 & 20.06 & 0.63 & Tinggi \\
Kontrol & 32 & 7.58 & 0.24 & Rendah \\
\hline
\end{tabular}

Berdasarkan Tabel 5diketahui bahwa rata-rata perkembangan kemampuan berpikir kritis siswa kelas eksperimen menunjukan kategori tinggi (0.63), sedangkan kelas kontrol berada pada kategori rendah (0.24). Kemampuan berpikir kritis siswa kelas eksperimen lebih baik dibandingkan kemampuan berpikir kritis kelas kontrol. 
Tabel 6 Nilai Rata-rata Pre tes, Pos tes dan N-gain Siswa pada Tiap Fungsi Kemampuan Berpikir Kritis.

\begin{tabular}{|c|c|c|c|c|c|c|c|c|c|}
\hline \multirow[t]{2}{*}{ Fungsi } & \multirow{2}{*}{$\begin{array}{l}\text { Nilai } \\
\text { Maks }\end{array}$} & \multicolumn{4}{|c|}{ Eksperimen } & \multicolumn{4}{|c|}{ Kontrol } \\
\hline & & $\begin{array}{l}\text { Pre } \\
\text { tes }\end{array}$ & $\begin{array}{l}\text { Pos } \\
\text { tes }\end{array}$ & $\begin{array}{l}\mathrm{N}- \\
\text { gain }\end{array}$ & kategori & $\begin{array}{l}\text { Pre } \\
\text { tes }\end{array}$ & $\begin{array}{l}\text { Pos } \\
\text { tes }\end{array}$ & $\begin{array}{l}\mathrm{N}- \\
\text { gain }\end{array}$ & Kategori \\
\hline $\begin{array}{l}\text { Pertanyaan } \\
\text { Terhadap } \\
\text { Masalah }\end{array}$ & 12 & $\begin{array}{c}5.8 \\
1\end{array}$ & $\begin{array}{c}8.0 \\
9\end{array}$ & 0.37 & Rendah & $\begin{array}{c}5.7 \\
8\end{array}$ & $\begin{array}{c}6.3 \\
8\end{array}$ & 0.10 & $\begin{array}{l}\text { Sangat } \\
\text { Rendah }\end{array}$ \\
\hline Tujuan & 12 & $\begin{array}{c}6.6 \\
3\end{array}$ & $\begin{array}{l}12 . \\
28\end{array}$ & 0.68 & Tinggi & $\begin{array}{c}6.5 \\
9\end{array}$ & $\begin{array}{c}8.2 \\
2\end{array}$ & 0.30 & Rendah \\
\hline Informasi & 12 & $\begin{array}{c}6.9 \\
4\end{array}$ & $\begin{array}{c}12 . \\
5\end{array}$ & 0.70 & Tinggi & $\begin{array}{c}6.3 \\
8\end{array}$ & $\begin{array}{c}7.7 \\
2\end{array}$ & 0.24 & Rendah \\
\hline Konsep & 20 & $\begin{array}{c}7.5 \\
3\end{array}$ & $\begin{array}{l}18 . \\
13\end{array}$ & 0.85 & $\begin{array}{l}\text { Sangat } \\
\text { Tinggi }\end{array}$ & 7.5 & $\begin{array}{l}12 . \\
41\end{array}$ & 0.39 & Rendah \\
\hline Asumsi & 8 & $\begin{array}{c}2.4 \\
7\end{array}$ & 4.5 & 0.37 & Rendah & $\begin{array}{c}0.4 \\
4\end{array}$ & 2 & 0.21 & Rendah \\
\hline $\begin{array}{l}\text { Sudut } \\
\text { pandang }\end{array}$ & 8 & $\begin{array}{c}0.7 \\
8\end{array}$ & $\begin{array}{c}5.3 \\
8\end{array}$ & 0.64 & Tinggi & $\begin{array}{c}0.7 \\
2\end{array}$ & $\begin{array}{c}1.5 \\
6\end{array}$ & 0.15 & $\begin{array}{l}\text { Sangat } \\
\text { Rendah }\end{array}$ \\
\hline $\begin{array}{l}\text { Interpretasi } \\
\text { dan } \\
\text { Inferensi }\end{array}$ & 20 & $\begin{array}{c}3.1 \\
6\end{array}$ & $\begin{array}{l}12 . \\
25\end{array}$ & 0.54 & Sedang & $\begin{array}{c}2.4 \\
7\end{array}$ & $\begin{array}{c}9.8 \\
4\end{array}$ & 0.42 & Sedang \\
\hline $\begin{array}{l}\text { Aplikasi } \\
\text { dan Akibat }\end{array}$ & 8 & $\begin{array}{c}4.0 \\
6\end{array}$ & 7.5 & 0.87 & $\begin{array}{l}\text { Sangat } \\
\text { Tinggi }\end{array}$ & $\begin{array}{c}4.8 \\
1\end{array}$ & $\begin{array}{c}5.1 \\
6\end{array}$ & 0.11 & $\begin{array}{l}\text { Sangat } \\
\text { Rendah }\end{array}$ \\
\hline
\end{tabular}

\section{Skala Sikap Ilmiah Siswa}

Hasil penelitian sikap ilmiah siswa kelas eksperimen dan kelas kontrol diperoleh dari hasil pre tes dasn pos tes, dengan membandingkan nilai pre tes dan nilai pos tes kedua kelas tersebut. Statistik deskriptif tentang sikap ilmiah siswa kelas eksperimen dan kelas kontrol sebelum dan sesudah pelaksanaan pembelajaran diperoleh dari skor awal sikap dan skor akhir sikap seperti ditampilkan dalam Tabel 7 berikut ini.

Tabel 7 Statistik Deskriptif Skor Sikap Ilmiah Awal dan Skor Sikap Ilmiah Akhir Siswa Kelas Eksperimen dan Kelas Kontrol

\begin{tabular}{llcccccc}
\hline Skor & Kelas & $\mathrm{N}$ & \multicolumn{5}{c}{ Skala Sikap Ilmiah } \\
\cline { 3 - 7 } & & $\begin{array}{c}\text { Skor } \\
\text { Maksi } \\
\text { mal }\end{array}$ & $\begin{array}{c}\text { Skor } \\
\text { Minimal } \\
\text { yang } \\
\text { diperoleh }\end{array}$ & $\begin{array}{c}\text { Skor } \\
\text { Maksimal } \\
\text { yang } \\
\text { diperoleh }\end{array}$ & $\bar{X}$ & $\mathrm{~S}$ \\
\hline Sikap & Eksperimen & 32 & \multirow{2}{*}{100} & 68 & 86 & 75.18 & 5.10 \\
Awal & Kontrol & 32 & & 68 & 84 & 76.68 & 4.94 \\
Sikap & Eksperimen & 32 & \multirow{2}{*}{100} & 70 & 94 & 84.5 & 7.14 \\
Akhir & Kontrol & 32 & & 68 & 88 & 77.88 & 5.05 \\
\hline
\end{tabular}

Keterangan:

N : Jumlah Siswa

$\bar{X} \quad$ : Rata-rata Nilai

S : Standar Deviasi 
Berdasarkan Tabel 7diketahui bahwa sebelum pembelajaran, rata-rata skor awal sikap ilmiah siswa kelas eksperimen dan kelas kontrol terhadap pembelajaran biologi khususnya pada saat pembelajaran konsep invertebrata tidak jauh berbeda. Setelah pembelajaran, rata-rata skor akhir sikap ilmiah siswa kelas eksperimen dan kelas kontrol terhadap pembelajaraan biologi mengalami perkembangan dan skor antara kedua kelas memiliki perbedaan. Untuk mengetahui signifikansi perbedaan rata-rata skor sikap awal dan sikap akhir siswa kelas eksperimen dan kelas kontrol, dilakukan uji perbedaan rata-rata. Sebelum dilakukan uji perbedaan rata-rata terlebih dahulu dilakukan uji normalitas dan homogenitas data sikap awal dan sikap akhir.

a. Uji Normalitas Skor Sikap Awal dan Sikap Akhir Kelas Eksperimen dengan Kelas Kontrol

Uji normalitas data sikap ilmiah siswa dalam penelitian ini di analisis dengan uji Kolmogorov-Smirnov Test pada program SPSS versi 18 (Uyanto, 2009) dengan kriteria pengujian pada taraf signifikansi $\alpha=0.05$. Data berdistribusi normal jika nilai Asymp. Sig (2-tailed) $\geq 0.05$. Hasil penghitungan uji normalitas data skor sikap awal dan sikap akhir sikap ilmiah kelas eksperimen dan kelas kontrol ditampilkan dalam Tabel 8berikut ini.

\section{Tabel 8 Hasil Uji Normalitas Skor Awal dan Skor Akhir Sikap IlmiahSiswaKelas} Eksperimen dan Kelas Kontrol.

\begin{tabular}{|c|c|c|c|c|}
\hline \multirow[t]{2}{*}{ Kolmogorov-Sminov } & \multicolumn{2}{|c|}{ Eksperimen } & \multicolumn{2}{|c|}{ Kontrol } \\
\hline & pre tes & pos test & pre tes & pos tes \\
\hline $\mathrm{N}$ (jumlah siswa) & 32 & 32 & 32 & 32 \\
\hline Mean & 75.18 & 76.68 & 84.5 & 77.88 \\
\hline Std. Deviasi & 5.10 & 4.94 & 5.28 & 5.05 \\
\hline A & 0.05 & 0.05 & 0.05 & 0.05 \\
\hline Asymp. Sig (2 tailed) & 0.20 & 0.11 & 0.82 & 0.20 \\
\hline Kesimpulan & Normal & Normal & Normal & Normal \\
\hline
\end{tabular}

Berasarkan Tabel 8diketahui bahwa nilai normalitas skor sikap awal, dan sikap akhir siswa kelas eksperimen dan kelas kontrol terhadap pembelajaran biologi khususnya konsep invertebrata melalui tes sikap ilmiah dengan skala rating pada taraf signifikansi $\alpha=0.05$ memenuhi criteria nilai Asymp. Sig (2-tailed) $\geq 0.05$. Hal ini menunjukkan bahwa nilai skor sikap awal dan sikap akhir sikap ilmiah siswaa kelas eksperimen dan kelas kontrol berdistribusi normal. 
b. Uji Homogenitas Skor Sikap Awal dan Sikap Akhir Sikap Ilmiah Siswa Kelas Eksperimen dengan Kelas Kontrol

Setelah diketahui bahwa skor sikap awal dan sikap akhir kelas eksperimen dan kelas kontrol berddistribusi normal maka dilanjutkan dengan uji homogenitas varians dengan menggunakan Uji Levene Statistic pada program SPSS versi 18. Kriteria pengujian untuk menyatakan bahwa varians kedua kelompok homogen adalah dengan mengambil taraf signifikansi $\alpha=0.05$. Varians kelas eksperimen dan kelas kontrol dikatakan homogen jika niali Sig. pada uji Levene Statistic $\geq 0.05$. Hasil perhitungan homogenitas varians skor sikap awal dan sikap akhir kelas eksperimen dan kelas kontrol disajikan dalam Tabel 9.

Tabel 9 Hasil Uji Homogenitas Varians Skor Sikap Awal dan Skor Sikap Akhir Kelas
\begin{tabular}{lccc} 
& \multicolumn{3}{c}{ Eksperimen dan Kelas Kontrol. } \\
\hline Levene Statistic & $\alpha$ & Sig. & Kesimpulan \\
\hline Pre tes & 0.05 & 0.014 & tidak homogen \\
Pos tes & 0.05 & 0.574 & homogen \\
\hline
\end{tabular}

Berdasarkan Tabel 9diketahui bahwa skor awal sikap ilmiah siswa (0.014) kelas eksperimen dengan kelas kontrol terhadap pembelajaran biologi pada taraf signifikansi $\alpha=$ 0.05 tidak memenuhi kriteria nilai sig. $\geq 0.05$, ini berarti bahwa bahwa varians kelas eksperimen dengan kelas kontrol tidak homogen. Sedangkan skor akhir sikap ilmiah siswa (0.574) kelas eksperimen dengan kelas kontrol terhadap pembelajaran biologi pada taraf signifikansi $\alpha=0.05$ memenuhi kriteria yaitu nilai $\operatorname{sig} \geq 0.05$, maka varians untuk sikap akhir kelas experiment dan kelas kontrol homogen.

c. Uji Perbedaan Dua Rata-rata Skor Sikap Awal dan Sikap Akhir Siswa Kelas Eksperimen dan Kelas Kontrol

Setelah dilakukan uji normalitas dan homogenitas terhadap data skor awal dan skor akhir sikap ilmiah siswa kelas eksperimen dan kelas kontrol diperoleh informasi bahwa skor awal sikap ilmiah siswa terhadap pembelajaran biologi berdistribusi normal dan tidak homogen sedangkan skor akhir sikap ilmiah siswa juga berdistribusi normal dan homogen. Perbedaan homogenitas tidak mempengaruhi uji selanjutnya. Oleh karena itu, untuk mengetahui signifikansi perbedaan skor awal dan skor akhir sikap ilmiah siswa kelas eksperimen dengan kelas kontrol, data diuji perbedaan dua rata-rata dengan menggunakan uji-t. Pengujian dilakukan berdasarkan hipotesis statistik berikut ini
Ho : $\mu_{1}=\mu_{2}$
Hi $: \mu_{1} \neq \mu_{2}$
$\mu_{1} \quad$ : Rata-rata skor awal sikap ilmiah kelas eksperimen
$\mu_{2}$ : Rata-rata skor awal sikap ilmiah kelas control 
Pada taraf signifikasi $\alpha=0.05 \mathrm{H}_{0}$ diterima jika $-\mathrm{t}_{1 / 2(1-\alpha)} \leq \mathrm{t}_{\text {hitung }} \leq \mathrm{t}_{1 / 2(1-\alpha)}$. Sedangkan pada keadaan lain $\mathrm{H}_{0}$ ditolak. Hasil perhitungan perbedaan rata-rata data skor awal dan skor akhir sikap ilmiah siswa kelompok experiment dengan kelompok kontrol disajikan dalam Tabel 10berikut ini.

\begin{tabular}{|c|c|c|c|c|c|c|c|c|}
\hline Data & Kelas & $\mathrm{N}$ & $\bar{X}$ & $\mathrm{~S}$ & $\mathrm{t}_{\mathrm{tab}}$ & $t_{\text {hit }}$ & $\begin{array}{l}\text { Penerimaan } \\
\mathrm{H}_{0}(\alpha=0.05)\end{array}$ & Kesimpulan \\
\hline \multirow[t]{2}{*}{$\begin{array}{l}\text { Pre } \\
\text { Tes }\end{array}$} & $\begin{array}{l}\text { Eksperi } \\
\text { men }\end{array}$ & 32 & 75.18 & 5.10 & \multirow{2}{*}{$\begin{array}{c}2.03 \\
9\end{array}$} & \multirow{2}{*}{2.29} & \multirow{2}{*}{ Tolak $\mathrm{H}_{0}$} & \multirow{2}{*}{$\begin{array}{c}\text { Berbeda } \\
\text { Signifikan }\end{array}$} \\
\hline & Kontrol & 32 & 76.68 & 4.94 & & & & \\
\hline \multirow[t]{2}{*}{$\begin{array}{l}\text { Pos } \\
\text { tes }\end{array}$} & $\begin{array}{l}\text { Eksperi } \\
\text { men }\end{array}$ & 32 & 84.5 & 7.14 & \multirow{2}{*}{$\begin{array}{c}2.03 \\
9\end{array}$} & \multirow{2}{*}{16.9} & \multirow{2}{*}{ Tolak $\mathrm{H}_{0}$} & \multirow{2}{*}{$\begin{array}{c}\text { Berbeda } \\
\text { Signifikan }\end{array}$} \\
\hline & Kontrol & 32 & 77.88 & 5.05 & & & & \\
\hline
\end{tabular}

Keterangan :

$\mathrm{N} \quad$ : Jumlah siswa $\quad \mathrm{t}_{\text {hit }} \quad$ : nilai hasil perhitungan uji $\mathrm{t}$

$\bar{X} \quad$ : rata-rata nilai $\quad t_{\text {tab }} \quad$ : nilai t tabel

S : Standar deviasi

Berdasarkan data pada Tabel 10diperoleh thitung skor awal sikap ilmiah siswa kelas eksperimen dan kelas kontrol dari skala sikap ilmiah berada pada daerah $\mathrm{t}_{\text {kritis }}$ untuk $\alpha=0.05$ uji dua pihak \pm 2.039 dan $\mathrm{t}_{\text {hitung }}=2.29$ sehingga dapat disimpulkan bahwa $\mathrm{H}_{0}$ ditolak. Hal ini dapat diartikan bahwa sikap ilmiah siswa kelas eksperimen dan kelas kontrol sebelum pembelajaran relative tidak sama atau

Skor akhir sikap ilmiah siswa kelas eksperimen dan kelas kontrol berada di luar daerah $\mathrm{t}_{\text {kritis }}$ untuk $\alpha=0.05$ uji dua pihak yaitu $\mathrm{t}_{\text {hitung }}=16.9$ sehingga dapat disimpulkan bahwa $\mathrm{H}_{0}$ ditolak. Hal ini dapat diartikan bahwa skor akhir sikap ilmiah siswa kelas eksperimen dan kelas kontrol berbeda signifikan.

d. Perhitungan Gain Ternormalisasi (N-Gain) Sikap Ilmiah Siswa Kelas Eksperimen dan Kelas Kontrol

Untuk Mengetahui kategori perkembangan skor sikap ilmiah siswa, maka dilakukan perhitungan gain ternormalisasi ( $\mathrm{N}$-gain) skor siswa kelas eksperimen dan kelas kontrol. Persentase perkembangan sikap ilmiah siswa terhadap pembelajaran biologi berdasarkan $\mathrm{N}$ gain sikap awal dan akhir kelas eksperimen dan kelas kontrol disajikan dalam Tabel 11 berikut ini.

Tabel 11 Persentase Kategori Gain Ternormalisasi (N-gain) Sikap Ilmiah Siswa Kelas Eksperimen dan Kelas Kontrol 


\begin{tabular}{ccccc}
\hline Kelas & $\begin{array}{c}\text { Jumlah Siswa } \\
(\mathrm{N})\end{array}$ & Jumlah & Rata-rata & Katagori \\
& 32 & 12.16 & 0.38 & Rendah \\
Eksperimen & 32 & 3.84 & 0.12 & Sangat Rendah \\
Kontrol & & &
\end{tabular}

Berdasarkan Tabel 11 diketahui bahwa perkembangan sikap ilmiah siswa kelas eksperimen berada pada kategori rendah (0.33) sedangkan sikap ilmiah siswa kelas kontrol berada pada kategori sangat rendah (0.12). Dengan kata lain, perkembangan sikap ilmiah siswa kelas eksperimen lebih baik dibandingkan dengan sikap ilmiah siswa kelas kontrol. Agar dapat terlihat secara jelas data hasil penelitian tentang sikap ilmiah siswa, dalam tabel 3. akan disajikan perbandingan nilai pre tes, pos tes dan $\mathrm{N}$-gain dari masing-masing indikator sikap ilmiah siswa menurut Carin (1997:14).

Tabel 12 Nilai Rata-Rata Pre tes, Pos tes, dan N-gain Sikap Ilmiah Siswa Setiap Indikator

\begin{tabular}{|c|c|c|c|c|c|c|c|c|c|}
\hline \multirow[t]{2}{*}{ Indikator } & \multirow{2}{*}{$\begin{array}{l}\text { Nilai } \\
\text { Maks }\end{array}$} & \multicolumn{4}{|c|}{ Eksperimen } & \multicolumn{4}{|c|}{ Kontrol } \\
\hline & & $\begin{array}{l}\text { Pre } \\
\text { tes }\end{array}$ & $\begin{array}{l}\text { Pos } \\
\text { tes }\end{array}$ & $\begin{array}{l}\mathrm{N}- \\
\text { gain }\end{array}$ & kategori & $\begin{array}{l}\text { Pre } \\
\text { tes }\end{array}$ & $\begin{array}{l}\text { Pos } \\
\text { tes }\end{array}$ & $\begin{array}{l}\mathrm{N}- \\
\text { gain }\end{array}$ & Kategori \\
\hline $\begin{array}{l}\text { Rasa Ingin } \\
\text { Tahu }\end{array}$ & 19 & $\begin{array}{l}14 . \\
09\end{array}$ & 17.71 & 0.74 & Tinggi & 14.84 & 15.72 & 0.21 & Rendah \\
\hline $\begin{array}{l}\text { Mengutamak } \\
\text { an Bukti }\end{array}$ & 12 & $\begin{array}{c}7.7 \\
2\end{array}$ & 9.09 & 0.32 & Rendah & 7.34 & 7.78 & 0.09 & $\begin{array}{l}\text { Sangat } \\
\text { Rendah }\end{array}$ \\
\hline $\begin{array}{l}\text { Bersikap } \\
\text { Skeptis }\end{array}$ & 9 & $\begin{array}{c}6.3 \\
4\end{array}$ & 6.94 & 0.22 & Rendah & 6.38 & 6.69 & 0.12 & $\begin{array}{l}\text { Sangat } \\
\text { Rendah }\end{array}$ \\
\hline $\begin{array}{l}\text { Menerima } \\
\text { Perbedaan }\end{array}$ & 14 & $\begin{array}{c}9.2 \\
5\end{array}$ & 10.53 & 0.27 & Rendah & 9.66 & 10.11 & 0.10 & $\begin{array}{l}\text { Sangat } \\
\text { Rendah }\end{array}$ \\
\hline $\begin{array}{l}\text { Bekerjasama } \\
\text { (kooperatif) }\end{array}$ & 13 & $\begin{array}{c}9.1 \\
3\end{array}$ & 10.47 & 0.35 & Rendah & 9.38 & 9.71 & 0.09 & $\begin{array}{l}\text { Sangat } \\
\text { Rendah }\end{array}$ \\
\hline $\begin{array}{l}\text { Bersikap } \\
\text { Positif }\end{array}$ & 19 & $\begin{array}{l}13 . \\
88\end{array}$ & 15.94 & 0.40 & Rendah & 14.47 & 14.94 & 0.10 & $\begin{array}{l}\text { Sangat } \\
\text { Rendah }\end{array}$ \\
\hline
\end{tabular}

\section{Angket Tanggapan Siswa terhadap Metode Pembelajaran}

Angket yang diberikan kepada siswa memberikan informasi tentang tanggapan siswa terhadap kegiatan praktikum yang dilakukan. Untuk mengungkap informasi yang dibutuhkan, pada angket tersebut diajukan beberapa pertanyaan yang berhubungan dengan kegiatan praktikum. Jawaban atas pertanyaan yang diberikan dengan cara memilih antara jawaban ya atau tidak, dan memberikan alasannya. Hasil pengolahan data angket siswa diinterpretasikan secara persentase dalam Tabel 13 berikut.

Tabel 13 Angket Tanggapan Siswa terhadap Metode Pembelajaran 


\begin{tabular}{|c|l|c|c|}
\hline No. & \multicolumn{1}{|c|}{ Pertanyaan } & $\begin{array}{c}\text { Ya } \\
(\%)\end{array}$ & $\begin{array}{c}\text { Tidak } \\
(\%)\end{array}$ \\
\hline 1. & $\begin{array}{l}\text { Apakah anda senang belajar dengan kegiatan praktikum } \\
\text { invertebrata? }\end{array}$ & 96 & 4 \\
\hline 2. & $\begin{array}{l}\text { Apakah dengan kegiatan praktikum dapat membantu anda } \\
\text { memahami materi invertebrata? }\end{array}$ & 100 & 0 \\
\hline 3. & $\begin{array}{l}\text { Apakah sebelumnya anda pernah belajar dengan kegiatan } \\
\text { praktikum? }\end{array}$ & 85 & 15 \\
\hline 4. & $\begin{array}{l}\text { Apakah dengan kegiatan praktikum dapat meningkatkan minat } \\
\text { anda untuk belajar biologi khususnya konsep invertebrata. }\end{array}$ & 90 & 10 \\
\hline 5. & $\begin{array}{l}\text { Apakah menurut kalian pembelajaran dengan praktikum yang telah } \\
\text { dilakukan cukup baik/menarik untuk diterapkan pada konsep } \\
\text { selanjutnya? }\end{array}$ & 96 & 4 \\
\hline 6. & $\begin{array}{l}\text { Apakah dengan kegiatan praktimum dapat mengembangkan } \\
\text { kemampuan belajar berpikir anda (missal, kemampuan } \\
\text { menganalisis, membuat asumsi, interpretasi, menarik kesimpulan } \\
\text { serta kemampuan berpikir lainnya? }\end{array}$ & 97 & 3 \\
\hline 7. & $\begin{array}{l}\text { Apakah anda merasa kesulitan dalam mengikuti kegiatan } \\
\text { praktikum yang pernah kita lakukan? }\end{array}$ & 56 & 44 \\
\hline 8. & $\begin{array}{l}\text { Apakah Lembar Kerja Siswa (LKS) dapat menuntun anda } \\
\text { dalam melaksanakan kegiatan praktikum dan mudah dipahami? }\end{array}$ & 94 & 6 \\
\hline 9. & $\begin{array}{l}\text { Apakah pembelajaran yang diawali dengan praktikum dapat } \\
\text { memudahkan anda dalam mempelajari materi yang sedang } \\
\text { dibahas? }\end{array}$ & 62 & 38 \\
\hline 10. & $\begin{array}{l}\text { Apakah materi invertebrata menarik untuk dilakukan kegiatan } \\
\text { praktikum? }\end{array}$ & 97 & 3 \\
\hline
\end{tabular}

Berdasarkan persentase hasil perhitungan angket tanggapan siswa pada Tabel 13 di atas menunjukkan bahwa siswa memberikan tanggapan yang positif terhadap pembelajaran berbasis praktikum yang dilakukan. Hal ini terbukti dengan persentase tanggapan yang diberikan siswa. Sebagian siswa memilih jawaban positif dan hanya beberapa orang yang memdberikan tanggapan negatif terhadap pertanyaan-pertanyaan yang diberikan.

\section{KESIMPULAN}

Data hasil analisis diperoleh skor pre tes kemampuan berpikir kritis pada kelas eksperimen dan kelas kontrol dengan menggunakan soal pilihan ganda ditemukan hasil 0,2 dan 0,176 signifikan dengan nilai Asymp. Sig (2-tailed) $\geq 0,05$. Kelas eksperimen dan kelas kontrol memperoleh rata-rata skor pretest 67,84 dan 65,28 dari nilai maksimum 100.

Setelah proses pembelajaran berbasis praktikum dilakukan post test pada kelas eksperimen dan kelas kontrol. Nilai rata-rata post test untuk kelas eksperimen 88 dan kelas kontrol adalah 73,50. Terjadi peningkatan skor 20,16 untuk kelas eksperimen sedangkan untuk kelas kontrol adalah 8,22 Rata-rata kelas eksperimen lebih tinggi daripada dengan kelas kontrol. Kemudian Nilai pengembangan awal sikap ilmiah untuk rata-rata kelas eksperimen adalah 
76,68 sedangkan kelas kontrol adalah 75,18. Setelah proses pembelajaran menunjukan siswa telah memiliki sikap ilmiah dalam pembelajaran biologi hal ini dibuktikan dengan meningkatnya hasil nilai rata-rata sikap ilmiah siswa yaitu 84,5 untuk kelas eksperimen dan 77,88 untuk kelas kontrol. Hal ini didukung demi hasil angket dan wawancara guru dengan siswa.

\section{DAFTAR PUSTAKA}

Carin, Arthur A., and Sund Robert B. 1997. Teaching Science Through Discovery. Columbus, Ohio : Merill Publishing Co.

Fraenkel, R.J, \& Wallen, N.C. 2006. How to Design and Evaluate Research in Education. London: Mc. Graw Hill, Inc.

Gasong, D. 2006. Model Pembelajaran Konstruktivistik Sebagai Alternatif Mengatasi Masalah Pembelajaran. http://puslit.petra.ac.id/journals/interior/.

O. Koray\& M. S. Koskal. 2009. The effect of creative and critical thinking based laboratory applications on creative and logical thinkingabilities of prospective teachers. Asia-Pacific Forum on Science Learning and Teaching, Volume 10, Issue 1, Article 2, p.10

Liliasari. 2000. Pengembangan Model Pembelajaran Berdasarkan Konstruktivisme untuk Meningkatkan Keterampilan Berpikir Tingkat Tinggi. Makalah: Pusat Studi Komputer Sains IKIP Bandung:

Mimbs, A.C. 2005. Teaching from The Critical Thingking, Problem Based Curricular Approach: Strategies, Challenges, and Recommendations.Journal of Family and Consumer Sciences Education, 23, (2)

Sanjaya, W. 2008. Strategi Pembelajaran Berorientasi Standar Proses Pendidikan. Jakarta : Prenada Media.

Sugiharto, Kartika N.F. dan Farida Harahap. 2007. Psikologi Pendidikan. Yogyakarta. UNY Press.

Tytler, R. 2002. "Teaching for Understanding in Science: Student Conceptions Research, and Changing Views of Learning”. Australian Science Teachers Journal, 48(3), 14-21.

Uyanto, S.S. 2009. Pedoman Analisis Data dengan SPSS. Yogyakarta: Graha Ilmu`

Wiersma, W. 1994. Research Methods In Education. Massachusetts: A Simon and Schuster Company. 